\title{
Identification of alkylsalicylic acids in Lentisk oil (Pistacia lentiscus L.) and viability assay on Human Normal Dermal Fibroblasts $^{\text {is }}$
}

\author{
Nabiha Benalia ${ }^{1,2}$, Abdenour Boumechhour ${ }^{3}$, Sergio Ortiz ${ }^{1}$, Cristian A. Echague ${ }^{1}$, Thorsten Rose ${ }^{4}$, \\ Bernd L. Fiebich ${ }^{4}$, Smain Chemat ${ }^{3}$, Sylvie Michel $^{1}$, Brigitte Deguin ${ }^{1}$, Saliha Dahamna ${ }^{2}$ \\ and Sabrina Boutefnouchet ${ }^{1, *}$ \\ ${ }^{1}$ Université de Paris, UMR CNRS CiTCoM 8038, Faculté de Santé, 4, av. de l'Observatoire, 75006 Paris, France \\ ${ }^{2}$ Laboratory of Phytotherapy Applied to Chronic Diseases, Faculty of Natural and Life sciences, University Ferhat Abbas Setif 1 , Setif \\ 19000, Algeria \\ ${ }^{3}$ Extraction and Separation Techniques Team, Research Centre in Physical and Chemical Analysis (C.R.A.P.C), BP 384 Zone Industrielle \\ de Bousmail, CP 42004 Tipaza, Algeria \\ ${ }^{4}$ VivaCEll Biotechnology GmbH, Ferdinand-Porsche-Str. 5, D-79211 Denzlingen, Germany
}

Received 16 September 2020 - Accepted 10 February 2021

\begin{abstract}
Pistacia lentiscus L. (Anacardiaceae) is widely distributed in the Mediterranean basin. Its fruit oil is used in traditional medicine to treat burns, skin impairments as well as inflammatory diseases as soothing massage or internal use. An increased interest is spotted lately with several commercial brands are spun portraying the benefits of this oil but with no stringent regulations to ascertain its safe use as an edible or cosmeceutical product. This work concerned the investigation of secondary metabolites presents in Pistacia lentiscus fruits oil using both GC-MS and HPLC-DAD-MS technics, and the evaluation of cytotoxicity on human normal dermal fibroblasts to assess safety of use as cosmetic ingredient. This study stands as the first one to report the identification of alkylsalicylic acids in fruits oil and unsaponifiable fraction of Pistacia lentiscus fruit oil which calls for therefore, quantification of alkylsalicylic acids, known as skin irritants, in Pistacia lentiscus oil, used as nutraceuticals or cosmeceuticals by manufacturers.
\end{abstract}

Keywords: Lentisk / Pistacia lentiscus L. / Anacardiaceae / ginkgolic acid / alkylsalicylic acid / cytotoxicity

\begin{abstract}
Résumé - Identification d'acides alkylsalicyliques dans l'huile de Lentisque (Pistacia lentiscus L.) et effet sur la viabilité cellulaire de fibroblastes dermiques humains normaux. L'espèce Pistacia lentiscus $\mathrm{L}$. est largement répandue autour du bassin méditerranéen. L'huile de ses fruits est utilisée en médecine traditionnelle pour traiter les brûlures, les affections cutanées ainsi que les états inflammatoires en massage ou en usage interne. Un regain d'intérêt récent pour cette ressource à travers notamment différents produits commerciaux vantant ses propriétés médicinales a été noté, avec cependant peu de données concernant la qualité des produits distribués, en tant que cosmétiques ou aliments. Les présents travaux ont porté sur l'identification des métabolites présents dans différents échantillons d'huile par analyse GC-MS et HPLCDAD-MS, ainsi que sur l'évaluation de l'effet de l'huile et de son insaponifiable sur la viabilité cellulaire de fibroblastes dermiques humains normaux en vue de son utilisation en tant qu'ingrédient cosmétique. Cette étude rapporte pour la première fois la présence d'acides alkylsalicyliques dans l'huile de fruits de Pistacia lentiscus L. et de sa fraction insaponifiable, ce qui incite à envisager une quantification de ces constituants, connus comme irritants cutanés, par les fabricants de produits à visée cosmétique ou nutraceutique.
\end{abstract}

Mots clés : Lentisque / Pistacia lentiscus L. / Anacardiaceae / acides gingkoliques / acides alkylsalicyliques / cytotoxicité

\footnotetext{
th Contribution to the Topical Issue "Lipids and Cosmetics / Lipides et cosmétiques".

*Correspondence: sabrina.boutefnouchet@u-paris.fr
} 


\section{Introduction}

Lentisk, Pistacia lentiscus L. is an evergreen shrub or tree from Anacardiaceae family, largely known as Darou, dherou or Drou in North Africa, Listincu or Chessa in Sardinia; or Mastiha tree in Greece. Its repartition covers all the Mediterranean area, from the Iberic peninsula to the Middle East. Mastic is the oleoresin obtained from the tree after incision of its trunk and is produced in abundance by the Chia variety occurring in the Greek Chios Island. Despite the large use of mastic for medicinal or dietary purpose (Pachi et al., 2020), the application of vegetal oil obtained from fruits is still less known.

An archaeological study from the eastern Mediterranean brought evidence of fruit oil production via fruits' squeezing in Roman and high medieval sites in Sardinia island and Corsica. The same processing method exists also traditionally in eastern Algeria and Tunisia, but not described in the western part of Mediterranean, which may indicate the probable influence of Roman empire colonization. Lentisk oil was mainly used for lighting, treating burns and wounds, and as food dressing (Lanfranchi et al., 1999; Lanfranchi and Bui, 1998; Loi, 2010). Several reports indicated the limited geographical distribution of lentisk oil users with predominance use is linked to traditional pharmacopoeia of eastern and central parts of Algeria and Tunisia for the treatment of skin, respiratory conditions and rheumatism. According to Djerrou et al. study, the use of Pistacia lentiscus fixed oil reduced the inflammatory phase, stimulated wound contraction and reduced the epithelization period to those treated with pharmaceutical grade oitment Madecassol ${ }^{\circledR}$ (Djerrou et al., 2010). Maameri et al. combined it with honey and confirmed its superiority to accelerate wound healing via contraction compared to a commercial skin protector cicatryl@ (Maameri et al., 2012).

Chemical composition of Pistacia lentiscus oil has been mainly focusing on saponifiable fraction of the oil including fatty acids, phytosterols and tocopherols (Charef et al., 2008; Mezni et al., 2012; Trabelsi et al., 2012). However, an increased interest is spotted lately with several commercial brands are spun portraying the benefits of this oil but with no stringent regulations are in force to ascertain its safe use as an edible or cosmeceutical product. This emerging popularity calls for the establishment of quality indicators to ensure quality of marketed oils, reduce the risks of adulteration and/or misuse and ascertain its safe use.

Thus, in this study, we focused in Lentisk oil with an objective of two folds, the first one consists to compare fourteen oil samples in order to depict quality indicators by spotting differences in secondary metabolites profiles using both GC-MS and HPLC-DAD-MS technics, the second one was to assess cytotoxicity on human normal fibroblast to elaborate its potential safe use in dermatological applications.

\section{Materials and methods}

\subsection{Oil samples and reagents}

Artisanal samples were obtained from rural families located in the area of Jijel (Sidi abdelaziz, Settara, Ouled rabeh), Blida and Elkala (Eltaref) (see Supplementary
Material). Artisanal production consists in crushing of mature fruits collected during the period of end of autumn-beginning of winter, then submitted for maceration in cold water. In certain cases, the mixture may be heated to increase oil's yield. After filtration, the oil is separated from water by decantation to afford a yellow green viscous liquid. The obtained yields ranged between 16\% and 19\% (Lanfranchi and Bui, 1998). In parallel, semi-artisanal samples were obtained from two cooperatives: Ladjoudane (Akbou) and Bouannani (Jijel). These oils are prepared following the same process described earlier but extraction is realized using a hydraulic press equipped with fibre disks called "scourtins". In another part, six commercial samples were purchased in the same areas (Tabs. 1 and 2). Methanol (MeOH) HPLC grade, dimethylsulfoxide (DMSO), ethanol $(\mathrm{EtOH})$, gallic acid, quercetin, Folin-Ciocalteu reagent, $\mathrm{AlCl}_{3} \cdot 6 \mathrm{H}_{2} \mathrm{O}, \mathrm{Na}_{2} \mathrm{CO}_{3}, \mathrm{CH}_{3} \mathrm{COONa}$, $\mathrm{BF}_{3}$ (4\%)-methanol, and hexane were purchased from Sigma Aldrich (St. Louis, USA).

\subsection{Pistacia lentiscus L. oil composition}

Fatty acids are analyzed after transesterification using $\mathrm{BF}_{3}$ into their corresponding methyl-esters (Charef et al., 2008; Mezni et al., 2012; Trabelsi et al., 2012). Briefly, $50 \mathrm{mg}$ of oil are diluted in $1 \mathrm{~mL}$ hexane, to which $0.5 \mathrm{~mL}$ of BF3 (14\%)methanol is added. The mixture is kept at $60{ }^{\circ} \mathrm{C}$ during 30 minutes after which $1 \mathrm{~mL}$ of water added. Then, the organic phase containing the FAME mixture is separated for GC-MS and GC-FID analysis. Analyses are performed using GCMSQP2010 Ultra (Shimadzu Co. Kyoto. Japan) equipped with a fused silica capillary column (Rtx-5MS; $30 \mathrm{~m} \times 0.25 \mathrm{~mm}$ inner diameter, film thickness $0.25 \mu \mathrm{m}$, Thames Restek. UK), and an Agilent 5973N MS detector. GC-FID was performed with a Master GC-Dani, France, equipped with a HP5 column (5\% Phenyl-Hexyl, $100 \mathrm{~m}$, internal diameter $0.25 \mathrm{~mm}$, thickness $0.2 \mu \mathrm{m})$ and a FID detector.

The following analytical conditions are used: oven temperature is programmed to start at $140{ }^{\circ} \mathrm{C}$, hold for $1 \mathrm{~min}$, then increased to $200^{\circ} \mathrm{C}$ at a rate of $5^{\circ} \mathrm{C} / \mathrm{min}$, then hold for $3 \mathrm{~min}$, then increased to $215^{\circ} \mathrm{C}$ (rate $5^{\circ} \mathrm{C} / \mathrm{min}$, hold for $5 \mathrm{~min}$ ), then increased to $240^{\circ} \mathrm{C}$ at a rate of $10^{\circ} \mathrm{C} / \mathrm{min}$, and finally hold for $10.5 \mathrm{~min}$. Injector temperature is set at $270^{\circ} \mathrm{C}$; carrier gas: helium, flow, $0.95 \mathrm{~mL} / \mathrm{min}$; splitting ratio 1:20; injection volume: $1 \mu \mathrm{L}$; interface temperature: $240^{\circ} \mathrm{C}$; while for the mass spectrometry interface, the MS source temperature is set at $220^{\circ} \mathrm{C}$ with an ionization energy of $70 \mathrm{eV}$. For other volatiles analysis, the oven temperature is programmed at $70{ }^{\circ} \mathrm{C}$, hold for $5 \mathrm{~min}$, then increased to $120^{\circ} \mathrm{C}$ (rate $5^{\circ} \mathrm{C} / \mathrm{min}$, hold for $2 \mathrm{~min}$ ), then increased to $180^{\circ} \mathrm{C}$ (rate $30^{\circ} \mathrm{C} / \mathrm{min}$, hold on $12 \mathrm{~min}$ ), and finally increased to $270^{\circ} \mathrm{C}$ (rate $30^{\circ} \mathrm{C} / \mathrm{min}$, and kept for $2 \mathrm{~min}$. Fatty acids were identified by comparison of their recorded mass spectra with the NIST14 library and the calculated retention indices (RI) of corresponding FAME fatty acid methyl esters.

\subsection{Analysis of unsaponifiable fraction}

The recovery of unsaponifiable fraction for artisanal samples 3,7 , and 8 is conducted following the procedure described in AFNOR NF T 60-206. Briefly, $50 \mathrm{~mL}$ of $2 \mathrm{~N}$ 
Table 1. Fatty acids composition of artisanal Pistacia lentiscus L. oil.

\begin{tabular}{|c|c|c|c|c|c|c|c|c|c|c|c|}
\hline \multirow[t]{2}{*}{ Artisanal samples } & $\begin{array}{l}1 \\
\text { Bouanani }\end{array}$ & $\begin{array}{l}2 \\
\text { Akbou } 2015\end{array}$ & $\begin{array}{l}3 \\
\text { Akbou } 2017\end{array}$ & $\begin{array}{l}4 \\
\text { Settara }\end{array}$ & $\begin{array}{l}5 \\
\text { Ouled Rabah }\end{array}$ & $\begin{array}{l}6 \\
\text { Sidi Abdelaziz }\end{array}$ & $\begin{array}{l}7 \\
\text { El Kala }\end{array}$ & $\begin{array}{l}8 \\
\text { Blida }\end{array}$ & Mean & SD & RSD \\
\hline & \multicolumn{11}{|c|}{$\%$ Fatty acids } \\
\hline Palmitoleic acid 16:1 & 2.38 & 1.72 & 2.07 & 3.03 & 2.02 & 2.42 & 2.1 & 2.76 & 2.31 & 0.43 & 0.18 \\
\hline Palmitic acid 16:0 & 31.45 & 23.94 & 30.34 & 34.22 & 27.15 & 28.09 & 30.54 & 37.08 & 30.35 & 4.1 & 0.14 \\
\hline $\begin{array}{l}n \text {-Hexadecanoic } \\
\text { acid } 16: 0\end{array}$ & 0.19 & 0.36 & 0 & 0 & 0.17 & 0.17 & 0 & 0 & 0.11 & 0.13 & 1.2 \\
\hline Oleic acid 18:1 & 39.67 & 46.33 & 42.83 & 43.96 & 52.84 & 51.89 & 48.6 & 41.12 & 45.91 & 4.88 & 0.11 \\
\hline Stearic acid 18:0 & 6.12 & 2.73 & 6.63 & 2.19 & 2.2 & 1.11 & 1.15 & 1.87 & 3 & 2.16 & 0.72 \\
\hline $\begin{array}{l}\text { Saturated Fatty } \\
\text { acids SFA }\end{array}$ & 37.76 & 27.03 & 36.97 & 36.41 & 29.52 & 29.37 & 31.69 & 38.95 & 33.46 & - & - \\
\hline $\begin{array}{l}\text { Unsaturated Fatty } \\
\text { acids UFA }\end{array}$ & 58.03 & 69.38 & 62.05 & 62.97 & 69.38 & 69.55 & 67.57 & 59.86 & 64.85 & - & - \\
\hline
\end{tabular}

ethanolic solution of $\mathrm{KOH}$ are added to $5 \mathrm{~g}$ of oil. The mixture is then refluxed for one hour. After evaporation, $50 \mathrm{~mL}$ of water is added, the suspension is extracted three times with $100 \mathrm{~mL}$ diethyl ether $(3 \times 100 \mathrm{~mL})$, washed with aqueous $\mathrm{KOH}(0.5 \mathrm{~N})$ followed by water, then dried on anhydrous $\mathrm{Na}_{2} \mathrm{SO}_{4}$ and evaporated under vacuum. Then, derivatization into silyl esters is performed. Briefly, $5 \mathrm{mg}$ of unsaponifiable fraction are placed with $0.5 \mathrm{~mL}$ of pyridine in a $2 \mathrm{~mL}$ vial. Then, $0.1 \mathrm{~mL}$ of hexamethyldisilazane (HMDS) and $0.04 \mathrm{~mL}$ of trimethylchlorosilane (TMCS) are added and the reaction mixture is mixed using a vortex then centrifuged. From the supernatant of the silylated mixture, $1 \mu \mathrm{L}$ is directly submitted to GC-MS analysis. In this case, carrier gas is $\mathrm{H} 2$ with a flowrate of $1 \mathrm{~mL} / \mathrm{min}$ and a split 1:20, oven is programmed increasing from $180^{\circ} \mathrm{C}$ to $270^{\circ} \mathrm{C}$ at $8^{\circ} \mathrm{C} / \mathrm{min}$ with a hold at initial and final temperatures of 1 and $65 \mathrm{~min}$ respectively (Jasmica, 2001). MS Interface temperature is set at $240^{\circ} \mathrm{C}$ while MS source temperature is set at $220^{\circ} \mathrm{C}$ with an ionization energy of $70 \mathrm{eV}$. The injection volume was $1 \mu \mathrm{L}$.

\subsection{HPLC-DAD-MS identification of alkylsalicylic acids in Pistacia lentiscus oil.}

Oil samples are analyzed on a HPLC-DAD-MS Thermo Scientific Dionex U3000 (Thermo-Dionex, Les Ulis, France) consisted of a quaternary pump (LPG-3400 SD), a thermostated autosampler (WPS-3000TSL), a thermostated column (TCC-3000SD), and a diode array detector (DAD-3000) on line with a quadrupole mass spectrometer (Surveyor MSQ plus System (Thermo-Dionex, Les Ulis, France). All oil samples were diluted in methanol $(10 \mathrm{mg} / \mathrm{mL})$. Solutions are filtered before injection on UptiDisc $0.45 \mathrm{M}$ nylon filters (Interchim, Montluçon, France). $20 \mu \mathrm{L}$ of each solution are injected and chromatograms are recorded at 210, 280, and $320 \mathrm{~nm}$. Oven temperature is set at $30^{\circ} \mathrm{C}$ and the analysis is performed using a gradient elution: $\mathrm{A}\left(\mathrm{H}_{2} \mathrm{O}, 0,5 \%\right.$ formic acid) and $\mathrm{B}(\mathrm{ACN}$,
$0.5 \%$ formic acid) as follows: $5 \%$ of $\mathrm{B}(0-10 \mathrm{~min}$, isocratic), $5 \%$ to $100 \%$ of B (10-40 min, linear gradient), $100 \%$ of B ( 40 $60 \mathrm{~min}$, isocratic), $100 \%$ to $5 \%$ of $\mathrm{B}(60-70 \mathrm{~min}$, linear gradient), $5 \%$ of $\mathrm{B}(70-75$ isocratic) the flow rate is fixed at $0.5 \mathrm{~mL} / \mathrm{min}$.

\subsection{Alamar blue cell viability assay on Normal Human Dermal Fibroblasts}

Normal Human Dermal Fibroblasts (NHDF) are cultured in Dulbecco's modified Eagle medium (Sigma, UK) supplemented with $10 \%$ fetal calf serum (Biowest Ltd., UK), $2 \%$ l-glutamine (Sigma), $100 \mathrm{U} / \mathrm{ml}$ penicillin, (Sigma), and $100 \mathrm{~g} / \mathrm{ml}$ streptomycin (Sigma). After counting the number of cells in a particle counter (Euro Diagnostics, Krefeld, Germany), NHDF are seeded in 96-well plates at a density of 8000 cells/well and incubated at $37^{\circ} \mathrm{C}$ with $5 \% \mathrm{CO}_{2}$ overnight. Cells are treated by $1 \mu \mathrm{L}$ of a $0.1,1,5,10,25,50$ and $100 \mu \mathrm{g} / \mathrm{ml}$ whole oil samples solution, or with $1 \mu \mathrm{L}$ of DMSO only (control), in $100 \mu \mathrm{L}$ of media. The experiment is conducted in quadruplicates. After $24 \mathrm{~h}$ of incubation, $10 \mu \mathrm{L}$ AlamarBlue ${ }^{\circledR}$ (Thermo Fisher Scientific, Waltham, MA, USA) is added to each well. After $2 \mathrm{~h}$, the fluorescence is measured with a fluorescence spectrophotometer (Polarstar, BMG, Offenbug) using 544EX $\mathrm{nm} / 590 \mathrm{EM} \mathrm{nm}$ filter settings. The amount of fluorescence is proportional to the number of living cells and corresponds to the cells' metabolic activity. Damaged and nonviable cells have lower innate metabolic activity and thus generate a proportionally lower signal than healthy cells. The active ingredient of AlamarBlue ${ }^{\circledR}$ (resazurin) is a nontoxic, cell permeable compound that is blue in color and virtually nonfluorescent. Upon entering cells, resazurin is reduced to resorufin, which produces very bright red fluorescence. Viable cells continuously convert resazurin to resorufin, thereby generating a quantitative measure of viability and cytotoxicity (Rampersad, 2012). 
Table 2. Fatty acids composition of commercial Pistacia lentiscus L. oil.

\begin{tabular}{|c|c|c|c|c|c|c|c|c|c|}
\hline \multirow[t]{2}{*}{ Commercial samples } & $\begin{array}{l}9 \\
\text { El Wafia }\end{array}$ & $\begin{array}{l}10 \\
\text { Zazia }\end{array}$ & $\begin{array}{l}11 \\
\text { Belkis }\end{array}$ & $\begin{array}{l}12 \\
\text { Zahrat el Atibaa }\end{array}$ & $\begin{array}{l}13 \\
\mathrm{Al} \text { Foursan }\end{array}$ & $\begin{array}{l}14 \\
\text { Sultane }\end{array}$ & Mean & SD & RSD \\
\hline & \multicolumn{9}{|c|}{$\%$ Fatty acids } \\
\hline Palmitoleic acid 16:1 & 0.13 & 0 & 2.03 & 1.69 & 2.31 & 1.28 & 1.24 & 0.97 & 0.79 \\
\hline Palmitic acid 16:0 & 16.41 & 16.25 & 24.78 & 31.58 & 28.42 & 22.35 & 23.3 & 6.25 & 0.27 \\
\hline$n$-Hexadecanoic acid 16:0 & 0 & 0 & 0 & 0 & 0 & 0 & 0 & 0 & 0 \\
\hline Stearic acid 18:0 & 5.28 & 5.16 & 2.14 & 1.3 & 2.15 & 1.84 & 2.98 & 1.76 & 0.59 \\
\hline Saturated Fatty acids SFA & 21.69 & 21.41 & 26.92 & 32.88 & 30.57 & 24.19 & 26.28 & - & - \\
\hline Unsaturated Fatty acids UFA & 76.31 & 76.3 & 72.11 & 66.64 & 67.79 & 75.47 & 72.44 & - & - \\
\hline UFA/SFA & 3.52 & 3.56 & 2.68 & 2.03 & 2.22 & 3.12 & 2.85 & - & - \\
\hline
\end{tabular}

\section{Results}

\subsection{Fatty acid and volatile compounds from Pistacia lentiscus L. fruits oil}

Pistacia lentiscus fruits oils from artisanal and commercial samples are mainly constituted by oleic acid (18:1), palmitic acid (16:0), linoleic acid (18:2), and palmitoleic acid (16:1) with a $3 / 2 / 1 / 0.1$ ratio, being the four main fatty acids presenting more than $90 \%$ of fatty acids in these oils (Tabs. 1 and 2). These results are in accordance with data reported in the literature for Tunisian and Algerian samples (Charef et al., 2008; Mezni et al., 2012; Trabelsi et al., 2012). However, two commercial samples show very different fatty acid profiles with inversed ratio of linoleic and oleic acids, revealing probable adulteration of these two commercial products, as higher ratio of linoleic acid can be a consequence of linoleic rich oil addition such a sunflower oil (Christopoulou et al., 2004). The results indicate that Pistacia lentiscus oils present a medium UFA/SFA ratio between 1.54 and 2.57. Mezni et al. reported higher UFA/SFA ratio ranging between 2.33 and 2.84 (Mezni et al., 2012). In addition, other reports showed similar higher ratios as well (Charef et al., 2008; Trabelsi et al., 2012). These differences can be explained by differences in oil extraction protocols and systems. In fact, Charef et al. used Soxhlet extraction using hexane and Trabelsi et al. used petroleum ether by means of a Soxhlet extraction; whereas artisanal samples from this study were produced using traditional mechanical oil extraction methods.

In order to identify specific markers of Pistacia lentiscus oil using GC-MS, identification of other volatiles after derivatization are also examined. Monoterpenes are identified from retention times $\mathrm{Rt}=5 \mathrm{~min}$ to $\mathrm{Rt}=15 \mathrm{~min}$ (Tab. 3). Major monoterpenes are identified as $\alpha$-pinene, myrcene, and $\beta$-limonene, largely reported in Pistacia lentiscus fruits and oil (Wyllie et al., 2006; Mecherara-Idjeri et al., 2008). Myrcene is the most abundant monoterpene representing more than $50 \%$ of detected monoterpenes. Monoterpenes' fraction may represent from 2.37 to $20.43 \%$ of all the identified volatiles compounds in the artisanal samples. Regarding artisanal samples (1-8), sample 7 (El Kala) presented the highest monoterpene fraction representing $20.43 \%$ of the detected compounds, versus only $2.36 \%$ for sample 2 (Akbou 2015) (Tab. 3). For commercial samples 9 (El Wafia) and 10 (Zazia), the monoterpenes fraction is nearly absent or not significant $(0,26 \%)$, which confirms eventual adulteration of the samples, whereas other commercial samples (11-14) have a monoterpene fraction similar to those of artisanal samples which confirm their authenticity. It is interesting to note that from $\mathrm{Rt}=15 \mathrm{~min}$ to $\mathrm{Rt}=20 \mathrm{~min}$, some sesquiterpenes could be identified by in small amount.

After $34 \mathrm{~min}$, traces of alkylphenols are identified using NIST library. The major MS fragments $\mathrm{m} / \mathrm{z}$ value were 108 and 120. The literature report that GC/MS-based identification of cardanols from Rhus species describe the hydroxytropilium ion with a m/z value of 108 as a common fragment for all the identified alkylphenols (Franke et al., 2001) (Tab. 3). Alkyl side chains for identified compounds vary from 13 to 17 carbons and may present a probable unsaturation (Fig. 1). Occurrence of alkylphenols is considered a critical finding because of the irritating potential of these compounds in Anacardiaceae and Ginkgoaceae species.

\subsection{Pistacia lentiscus L. fruits oil unsaponifiable composition}

Unsaponifiable extraction was considered for artisanal samples 2, 7, and 8 following AFNOR NF T 60-206. Unsaponifiable yields were respectively 1.67, 0.47 and $1.07 \%$. Composition of unsaponifiable fractions iwas analyzed using GC-MS after derivatization into silyl esters. Phytosterols and alkylsalicylic derivatives are identified using NIST library (Song et al., 2000; Wang et al., 2014). Five alkylsalicylic acids were identified between 11.5 and $14 \mathrm{~min}$ as C15:1, C15:0 and C17:1 derivatives. In this case, the diagnosis MS fragments was 180 (Tab. 4). In respect to phytosterols, identified between 26 and $36 \mathrm{~min}, \beta$-sitosterol is the main identified phytosterol, stigmasterol and campesterol are also identified but in smaller proportions. 


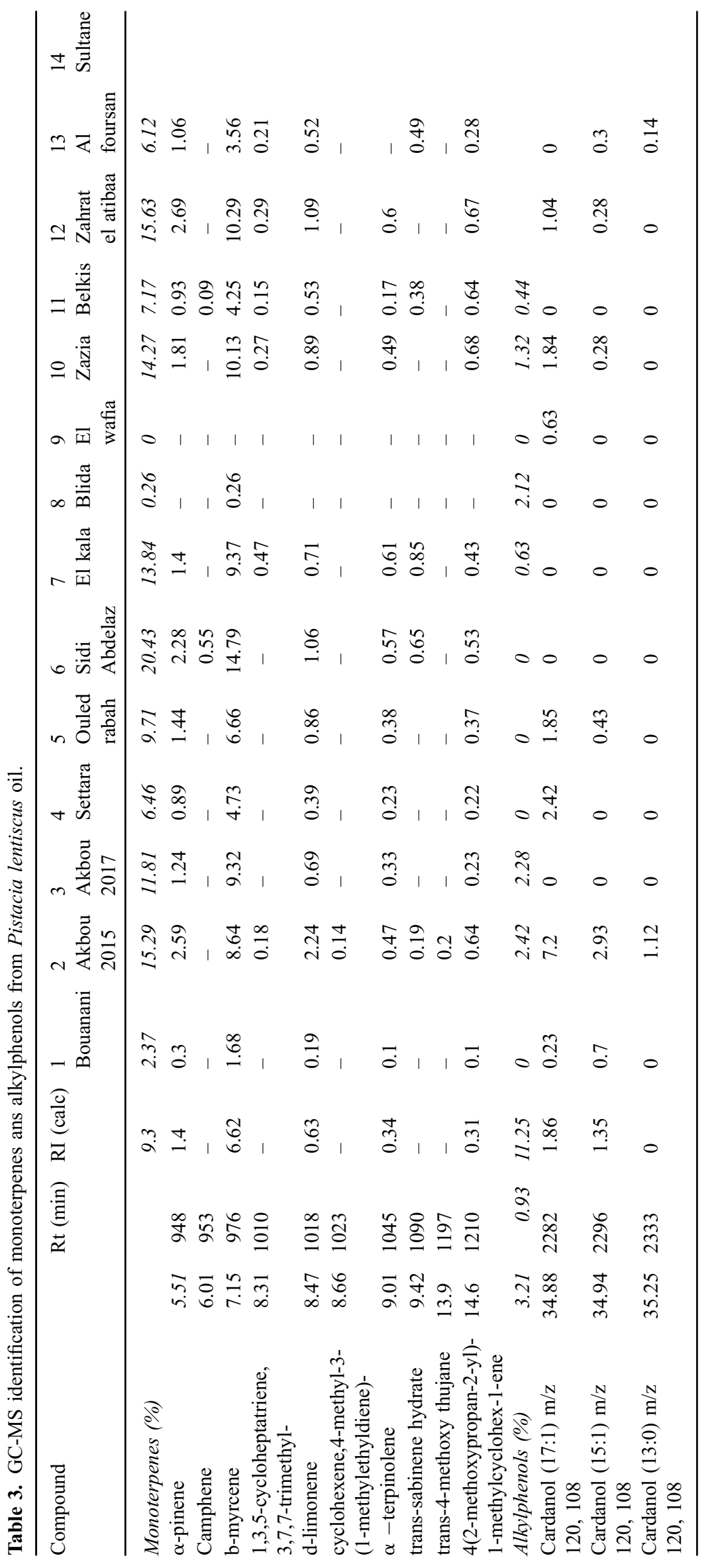


$\mathrm{R}_{1}=\mathrm{C}_{13} \mathrm{H}_{27}(13: 0)$

$\mathrm{R}_{1}=\mathrm{C}_{15} \mathrm{H}_{31}(15: 0)$

$\mathrm{R}_{1}=\mathrm{C}_{15} \mathrm{H}_{29}(15: 1)$

$\mathrm{R}_{1}=\mathrm{C}_{17} \mathrm{H}_{33}(17: 1)$

$\mathrm{R}_{1}=\mathrm{C}_{17} \mathrm{H}_{31}(17: 2)$

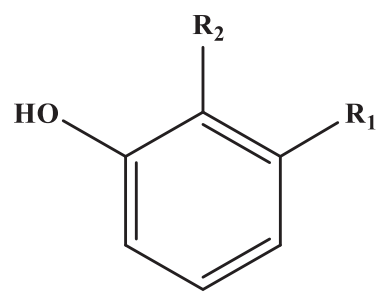

Alkylphenols $\mathrm{R}_{2}=\mathrm{H}$, Alkyl salicylic acids $\mathrm{R}_{2}=\mathrm{COOH}$

Fig. 1. General structures of alkylphenols and alkylsalicylic acids.

\subsection{Alkylsalicylic acids from Pistacia lentiscus L. fruits oil}

As this is the first report demonstrating the occurence of alkylphenols or alkylsalicylic acids in Pistacia lentiscus L. oil, HPLC-DAD-MS analysis was envisaged with comparison of oil samples 1-14 to the 3-(heptadec-8-en-1-yl)-salicylic acid standard from PLFE1 fruit fraction. PLFE1 is a non-polar fraction rich in alkylsalicylic acids, is isolated from fruits of Algerian Pistacia lentiscus and characterized in a previous work (Tahrioui et al., 2020). PLFE1 contains 3-(heptadec-8en-1-yl)-salicylic acid, also known as ginkgolic acid (C17:1), together with hydroginkgolic acid (C15:0). The structure of $\Delta 8$ ginkgolic acid (C17:1) have been confirmed after isolation from the PLFE1 extract using NMR analysis, whereas the double bound position was confirmed by ozonolysis (Tahrioui et al., 2020).

From HPLC-UV/DAD-MS analysis, similarity with UV spectra and $\mathrm{m} / \mathrm{z}$ values in negative mode confirmed the identification of previously isolated alkylsalicylic acids in the non-polar fruit extract PLFE1. Figure 2 shows that alkylsalicylic acids derivatives are detected in oil samples between 44 and $60 \mathrm{~min}$ with the same distribution profile for 4 main compounds. Among the four detected derivatives, the main compounds were ginkgolic acid $(\mathrm{C} 17: 1)$ with a $\mathrm{m} / \mathrm{z}$ value of 373 in negative mode, together with ginkgolic acid (C15:1) $(\mathrm{m} / \mathrm{z}$ 345). The $\mathrm{C} 17: 2$ derivative and the minor $\mathrm{C} 13: 0$ derivative are also identified $(\mathrm{m} / \mathrm{z}$ respectively 370.9 and 319 ) with similar typical UV spectra with two characteristic $\lambda \max$ at 247 and $314 \mathrm{~nm}$.

\subsection{Cytotoxic assessment on Normal Human Dermal Fibroblasts (NHDF)}

Cell viability assay performed in NHDF cells revealed only a low cellular toxicity of oil samples for all concentrations tested ( 0.1 to $100 \mu \mathrm{g} / \mathrm{mL}$ ), however, we detected a loss of cell viability for all unsaponifiable samples at concentrations higher than $50 \mu \mathrm{g} / \mathrm{mL}$. At $100 \mu \mathrm{g} / \mathrm{mL}$, cell viability for all unsaponifiable tested samples were below 50\% (Fig. 3). These results may be linked to the presence of identified metabolites in the unsaponifiable. Regarding the different identified metabolites (phytosterols, alkylsalicylic acids, carotenoids), alkyl phenols and alkylsalicylic may be the highest contributors to this cytotoxicity as dermal toxicity of these class of compounds has already been described, such as contact dermatitis. It can be noticed that loss of viability was slightly higher for unsaponifiable fraction of oil sample 7 which is constituted of a higher proportion of alkylsalicylic acid 15:1.

\section{Discussion}

Studied artisanal and commercial samples of Pistacia lentiscus oils were quite homogeneous in terms of fatty acids composition with oleic acid (18:1), palmitic acid (16:0), linoleic acid (18:2), and palmitoleic acid (16:1) profiling a $3 / 2 / 1 / 0.1$ ratio, although two of the seven commercial samples are found to be adulterated (Tabs. 1 and 2). Differences in trace secondary metabolites helped us identify alkylphenols derivatives as quality markers for Pistacia lentiscus fruit oils. HPLC-UV-DAD-MS confirmed that these alkylphenols are in fact alkylsalicylic acids after comparison with purified standards (Fig. 2). The 17:1 alkyl salicylic acid derivative is found to be the major derivative together with the 15:1 derivative. To the best of our knowledge, this is the first study to report the occurrence of alkylsalicylic acids (ASAs) in Pistacia lentiscus fruit oil. Previous identification of ASA in Pistacia lentiscus included previous authors findings of these ASAs in the non-polar fraction of the fruits particularly the 3(heptadec-8-en-1-yl)-salicylic acid also known as ginkgolic acid $(\Delta 8 \mathrm{C} 17: 1)$ where the position of the double bound is determined using ozonolyisis (Tahrioui et al., 2020). This class of secondary metabolites is reported in other Anacadiaceae species, such as Anacardium occidentale, but also in Gingkoaceae species. Identification of alkylsalicylic acids by LC-MS and GC-MS is mainly described for Ginkgo biloba as quality requirements of phytopharmaceutical products requires limited amounts of ginkgolic acids (Abate-Pella, 2017). Alkylsalicylic acids could be identified in Ginkgo biloba leaves by GC-MS thanks to the characteristic fragmentation pattern with a typical fragment with $\mathrm{m} / \mathrm{z}$ value of 180 described by Wang et al. for methyl esters derivatives (Wang et al., 2014). Alkylsalicylic acids' profile in Ginkgo biloba leaves are quite different as the 15:1 ginkgolic acid, either $\Delta 8$ or $\Delta 10$, is the major derivative. Wang et al. determined the $\Delta 8 / \Delta 10$ ratio using commercial standards on a HP- 88 high polarity column, as the $\Delta 8$ compound retention time is slightly lower. In this study, GC-MS is performed with a RTx-5 non polar column. Indeed, two isomers of the 15:1 and 17:1 alkylsalicylic derivatives could be identified, without clear identification of each isomer. The availability of the purified standard fraction PLFE1 allowed us the identification of $\Delta 8 \quad 17: 1$ derivative as the major alkyl salicylic acid compound present in Pistacia lentiscus fruit oil.Alkylsalicylic acids, such as ginkgolic or anacardic acids, have been described as toxic compounds responsible for cutaneous irritation or allergy (Kajiyama et al., 2002; Ndjoko et al., 2000). However, this cutaneous toxicity observed after consumption of Ginkgo biloba, is still under scrutiny. Indeed, alkyl resorcinols, such as ginkgols and cardanols, or catechol derivatives, such as urushiols from Anacadiaceae species, are highly toxic as the resorcinol and catechol moiety might be transformed into quinones responsible of severe contact dermatitis (Knight et al., 1996; Aguilar-Ortigoza et al., 2003; Duthil, 2005). Alkylphenols and alkylresorcinols have also been identified in Ginkgo biloba leaves and may be responsible for the observed toxicity. Regarding alkylsalicylic acids 


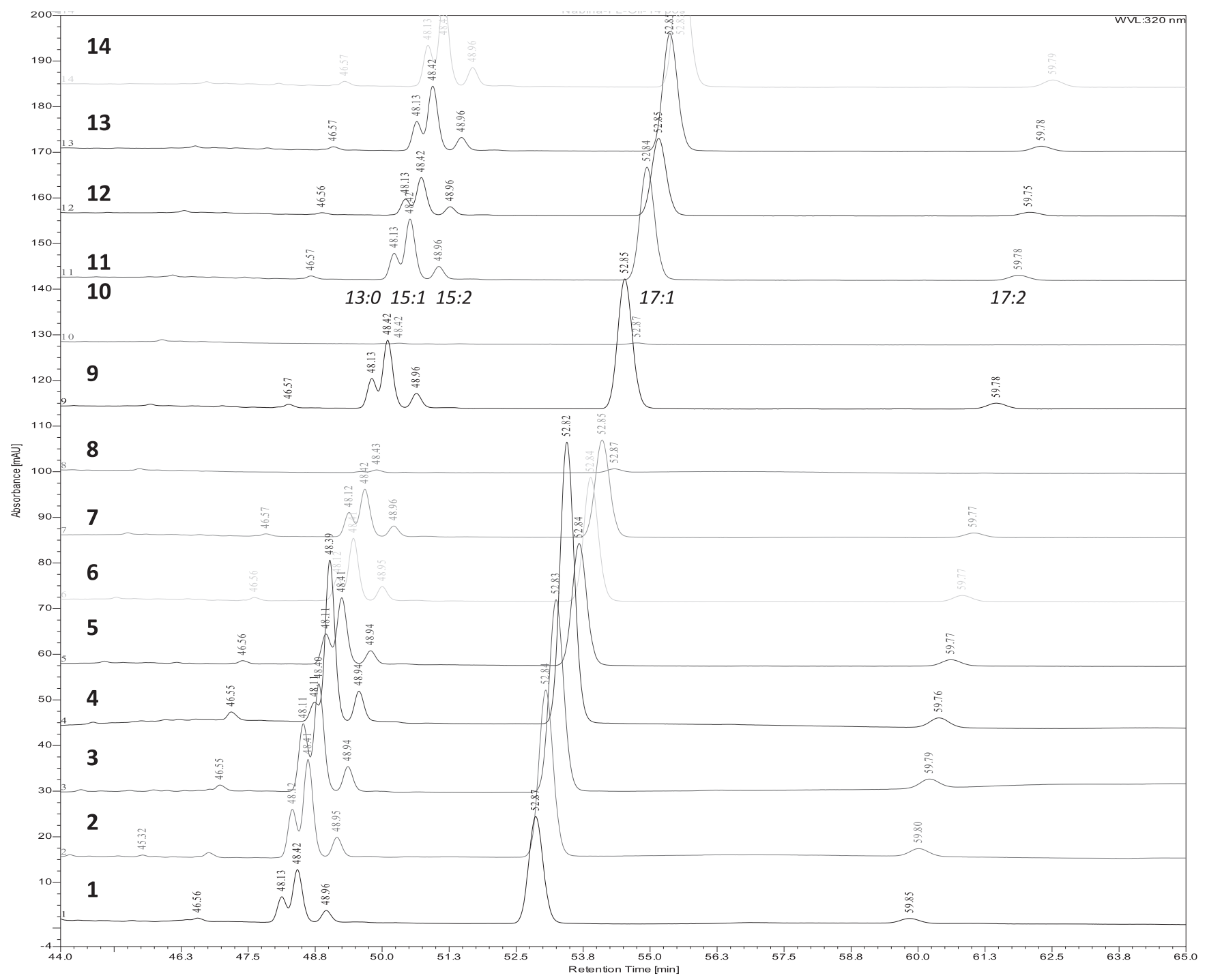

Fig. 2. HPLC-DAD-MS profiles of Pistacia lentiscus oil fractions (44 to $65 \mathrm{~min}$ ) showing the 5 main identified alkylsalicylic acids: C 13:0, C 15:1, C 15:2, C 17:1 and C 17:2.

derivatives, with a single phenol function, it is not clear yet whether transformation into quinones might occur after metabolization or not. Baron Ruppert and Luepke gave some evidence of cytotoxicity of a ginkgolic acids (GA) rich fraction (16\% GA only) using the hen's egg test. The low level of GA in the tested fraction is still not sufficient to explain the toxicity of GA (Lomonaco et al., 2013). However, more recently, hepatotoxicity of pure ginkgolic acids have been reported in mice and rat models (Baron-Ruppert and Luepke, 2001). In the present work, evaluation of cytotoxicity on normal human dermal fibroblasts (NHDF) revealed that the unsaponifiable fraction can affect cell viability in fibroblasts, but this effect is not recorded for the oil (Fig. 3). While unsaponifiable fraction is rich in phyosterols and alkylsalicylic acids, toxicity assessment of phtoysterols in cosmetics revealed that they are usually not toxic (Jiang et al., 2017). Nevertheless, GA is considered a promising antitumor compound via the inhibition of the small ubiquitin-related modifiers SUMO-1 (Belsito et al., 2013) and as an antibacterial agent by inhibiting virulence factors such as biofilm formation or membrane stiffness (Tahrioui et al., 2020).

\section{Conclusion}

This work concerned the investigation of quality standards for Pistacia lentiscus fruits oil in commercial and artisanal samples lead to the identification of alkylsalicylic acids in fruits oil and unsaponifiable fraction of Pistacia lentiscus fruit oil. This is the first report of occurrence of alkylsalicylic acids in Pistacia lentiscus fruits oil. As alkylsalicylic acids are skin irritating agents, cytotoxicity evaluation on normal dermal human fibroblasts indicated that the oil is not toxic even at high concentrations, whereas unsaponifiable fraction containing higher amounts of alkylsalicylic derivatives are found to be toxic at concentrations above $50 \mu \mathrm{g} / \mathrm{mL}$. As quality standards required for Gingko biloba phytopharmaceutical products is fixed by a limit of $5 \mathrm{ppm}$ for alkylsalicylic acids is set; 

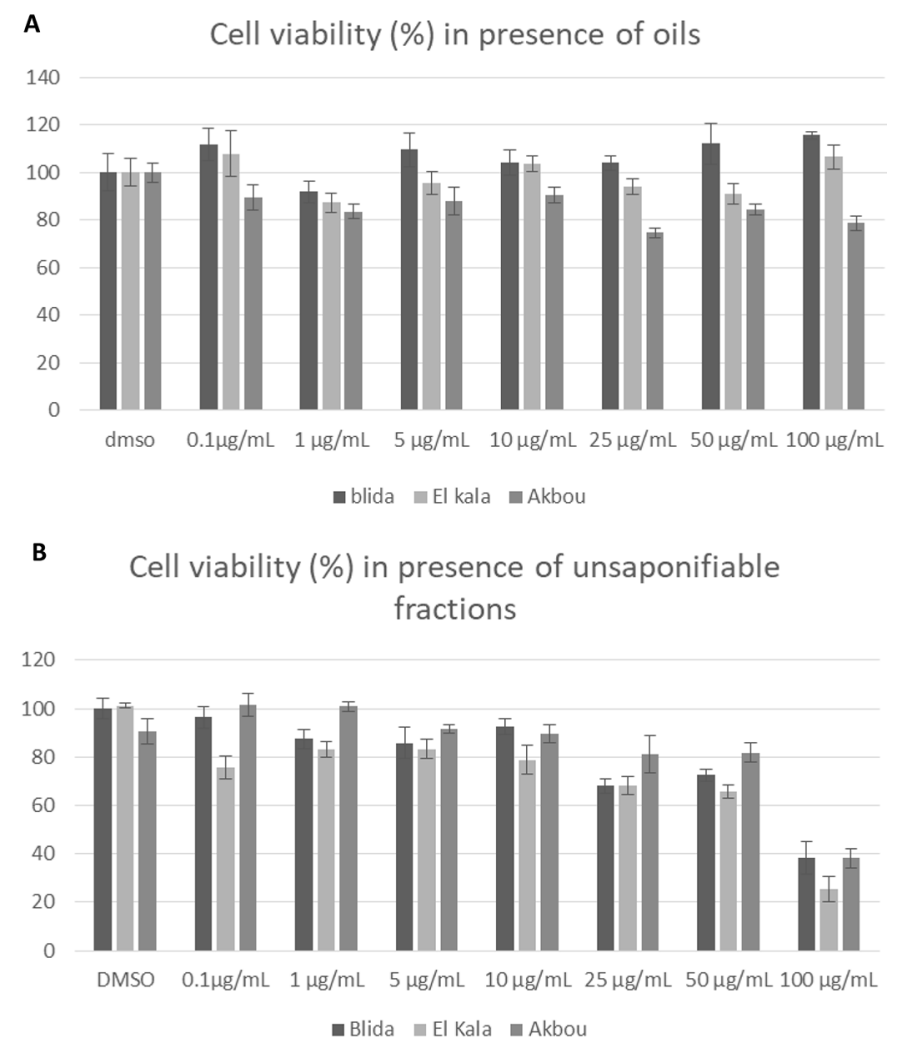

Fig. 3. \% of Cell viability (mean +:- SEM) of Normal Human Dermal Fibroblasts submitted to. (A): Pistacia lentiscus L. artisanal oil samples 3 (Akbou 2017), 7 (El Kala) and 8 (Blida) from 0.1 to $100 \mu \mathrm{g} / \mathrm{mL}$, (B) Unsaponifiable fraction of Pistacia lentiscus L. artisanal oil 3b (Akbou 2017), $7 \mathrm{~b}$ (El Kala) and $8 \mathrm{~b}$ (Blida) from 0.1 to $100 \mu \mathrm{g} / \mathrm{mL}$. (Control: DMSO).

Table 4. GC-MS identification of phytosterols and alkylsalicylic acids from unsaponifiable.

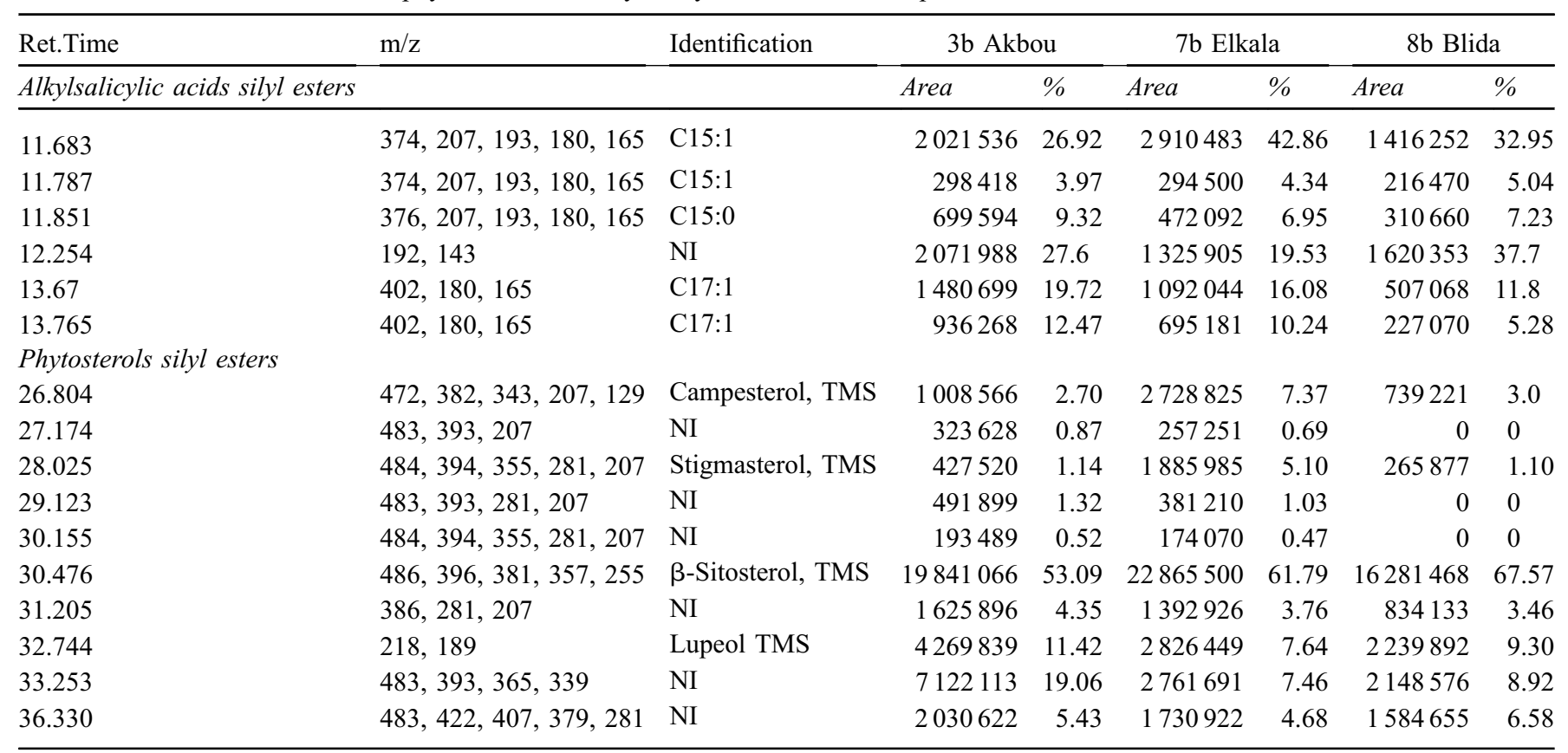


therefore, quantification of alkylsalicylic acids in Pistacia lentiscus oil both for nutraceutical or cosmeceutical use should be envisaged by manufacturers.

\section{Supplementary Material}

Identification of alkylsalicylic acids in Lentisk oil (Pistacia lentiscus L.) and 1 cytotoxicity on Human Normal Dermal Fibroblasts.

The Supplementary Material is available at http://www.ocljournal.org/10.1051/ocl/2021009/olm.

\section{Declaration of competing interest}

Authors declare that they have no known competing financial interests or personal relationships that could have appeared to influence the work reported in this paper.

Acknowledgments. Authors thank the funding program H2020 MSCA-RISE EXANDAS -EXploitation of Aromatic plaNts' by proDucts for the development of novel cosmeceuticAls and food Supplements-H2020-MSCA-RISE2015-Grant agreement No. 691247. https://www.exandasproject.eu/.

\section{Author contributions}

Conceptualization, methodology, S.B.; resources, S.B., N.B., S.C., formal analysis, S.B., N.B., A.B., S.O., T.R, B.L.F., investigation, S.B., N.B., A.B., S.O., E.C., T.R., data curation, N.B., S.B., A.B., S.O., E.C., T.R., writing-original draft preparation, S.B, N.B., T.R.; writing-review and editing, S.B., N.B., B.F., S.C., supervision, S.B., B.D., S.D., B.F.; project administration, S.B., B.D., S.D.; funding acquisition, S.B., B.D., S.M., S.D., S.C., B.F.

\section{References}

Aguilar-Ortigoza CJ, Sosa V, Aguilar-Ortigoza M. 2003. Toxic phenols in various Anacardiaceae species. Econ Bot 57: 354-364. https://doi.org/10.1663/0013-0001(2003)057[0354:TPIVAS]2.0. CO.

Baron-Ruppert G, Luepke NP. 2001. Evidence for toxic effects of alkylphenols from Ginkgo biloba in the hen's egg test (HET). Phytomedicine 8(2): 133-138. https://doi.org/10.1078/ 0944-7113-00022.

Belsito DV, Klaassen CD, Liebler DC, Hill RA. 2013. Safety Assessment of phytosterols as used in Cosmetics. cir-safety.org.

Charef M, Yousfi M, Saidi M. 2008. Determination of the Fatty Acid Composition of Acorn (Quercus), Pistacia lentiscus Seeds Growing in Algeria. J Am Oil Chem Soc 85: 921-924. https:// doi.org/10.1007/s11746-008-1283-1.

Christopoulou E, Lazaraki M, Komaitis M, Kaselimis K. 2004. Effectiveness of determinations of fatty acids and triglycerides for the detection of adulteration of olive oils with vegetable oils. Food Chem 84(3): 463-474. https://doi.org/10.1016/s0308-8146(03) 00273-5.
Djerrou Z, Maameri Z, Hamdi-Pacha Y, et al. 2010. Effect of Virgin Fatty Oil of Pistacia lentiscus on Experimental Burn Wound's Healing in Rabbits. Afr J Trad Compl Altern Med 7(3): 258-263. https://doi.org/10.4314/ajtcam.v7i3.54788.

Duthil P. 2005. Usages alimentaire et pharmaceutique de l'amande du Ginkgo. Bull Soc Pharm Bordeaux 144: 301-310.

Franke K, Masaoud M, Schmidt J. 2001. Cardanols from leaves of Rhus thyrsiflora. Planta Med 67(5): 477-479. https://doi.org/ 10.1055/s-2001-15813.

Jiang L, Si ZH, Li MH, et al. 2017. 1H NMR-based metabolomics study of liver damage induced by ginkgolic acid $(15: 1)$ in mice. J Pharm Biomed Anal 136: 44-54. https://doi.org/10.1016/j. jpba.2016.12.033.

Kajiyama Y, Fujii K, Takeuchi H, Manabe Y. 2002. Ginkgo seed poisoning. Pediatrics 109(2): 325-327. https://doi.org/10.1542/ peds.109.2.325.

Knight TE, Boll P, Epstein WL, Prasad AK. 1996. Resorcinols and catechols: a clinical study of cross-sensitivity. Am J Contact Dermat 7(3): 138-145. https://doi.org/10.1016/S1046-199X(96) 90001-9.

Lanfranchi F, Bui T-M. 1998. L'oléastre et le lentisque, plantes oléagineuses sauvages dans l'économie néolithique en Corse et en Sardaigne. In: Sardinian and Aegean Chronology: Towards the Resolution of Relative and Absolute Dating in the Mediterranean. Studies in Sardinian Archaeology, Vol. 103. Oxford: Oxbow Books Ed., pp. 1-10.

Lanfranchi F, Bui T-M, Girard M. 1999. La fabrication d'huile de lentisque (Linsticu ou chessa) en Sardaigne. Journal d'agriculture traditionnelle et de botanique appliquée JATBA 41(2): 81-100. https://doi.org/10.3406/jatba.1999.3712.

Loi C. 2010. Preliminary Studies about the Productive Chain of Lentisk Oil through Ethnographic Witness and Experiments, Ethnoarchaeology: Current Research and Field Methods. In: Conference Proceedings, Rome, Italy, 13th-14th May 2010 (C) Archaeopress and the individual authors 2013, Archaeopress Publishers of British Archaeological Reports Gordon House, England.

Lomonaco D, Maia FJN, Mazzetto SE. 2013. Thermal evaluation of cashew nutshell liquid as new bioadditives for poly(methyl methacrylate). J Therm Anal Calorim 111: 619-626. https://doi. org/10.1007/s10973-012-2383-6.

Maameri Z, Beroual K, Djerrou Z, et al. 2012. Preliminary study to assess cicatrizing activity of honey and Pistacia lentiscus fatty oil mixture on experimental burns in rabbits. Int J Med Arom Plants 2 (3): 476-480.

Mecherara-Idjeri S, Hassani A, Vincent Castola V, Casanova J. 2008. Composition and Chemical Variability of the Essential Oil from Pistacia lentiscus L. Growing Wild in Algeria: Part II: Fruit Oil. $J$ Essent Oil Res 20(2): 104-107. https://doi.org/10.1080/ 10412905.2008.9699965.

Mezni F, Maaroufi A, Msallem M, Boussaid M, Khouja ML, Khaldi A. 2012. Fatty acid composition, antioxidant and antibacterial activities of Pistacia lentiscus L. seed oils. J Med Plant Res 6(39): 5266-5271. https://doi.org/10.5897/JMPR12.473.

Ndjoko K, Wolfender JL, Hostettmann K. 2000. Determination of trace amounts of ginkgolic acids in Ginkgo biloba L. leaf extracts and phytopharmaceuticals by liquid chromatography-electrospray mass spectrometry. J Chrom B 744(2): 249-255. https://doi. org/10.1016/s0378-4347(00)00316-9. 
Pachi VK, Mikropoulou EV, Gkiouvetidis P, et al. 2020. Traditional uses, phytochemistry and pharmacology of Chios mastic gum (Pistacia lentiscus var. Chia, Anacardiaceae): A review. $J$ Ethnopharmacol, in press. https://doi.org/10.1016/j. jep.2019.112485.

Rampersad SN. 2012. Multiple Applications of Alamar Blue as an Indicator of Metabolic Function and Cellular Health in Cell Viability Bioassays. Sensors 12: 12347-12360. https://doi.org/ 10.3390/s120912347.

Song YS, Jin C, Park EH. 2000. Identification of metabolites of phytosterols in rat feces using GC/MS. Arch Pharm Res 23(6): 599-604. https://doi.org/10.1007/BF02975248.

Tahrioui A, Ortiz S, Azuama OC, et al. 2020. Membrane-Interactive Compounds From Pistacia lentiscus L. Thwart Pseudomonas aeruginosa Virulence. Front Microbiol 11: 1068. https://doi.org/ 10.3389/fmicb.2020.01068.

Trabelsi H, Cherif OA, Sakouhi F. 2012. Total lipid content, fatty acids and 4-desmethylsterols accumulation in developing fruit of Pistacia lentiscus L. growing wild in Tunisia. Food Chem 131(2): 434-440. https://doi.org/10.1016/j.foodchem.2011.08.083.

Wang M, Zhao J, Avula B, et al. 2014. High-resolution gas chromatography/mass spectrometry method for characterization and quantitative analysis of ginkgolic acids in Ginkgo biloba plants, extracts, and dietary supplements. J Agric Food Chem 62(50): 21032111. https://doi.org/10.1021/jf503980f. Epub 2014 Dec 2. PMID: 25383633.

Wyllie S, Brophy JJ, Sarafis V, Hobbs M. 2006. Volatile Components of the Fruit of Pistacia lentiscus. J Food Sci 55: 1325-1326. https://doi.org/10.1111/j.1365-2621.1990.tb03926.x.

Cite this article as: Benalia N, Boumechhour A, Ortiz S, Echague CA, Rose T, Fiebich BL, Chemat S, Michel S, Deguin B, Dahamna S, Boutefnouchet S. 2021. Identification of alkylsalicylic acids in Lentisk oil (Pistacia lentiscus L.) and viability assay on Human Normal Dermal Fibroblasts. OCL 28: 22. 